\title{
Health treaty dilution: a case study of Japan's influence on the language of the WHO Framework Convention on Tobacco Control
}

\author{
Mary Assunta, Simon Chapman
}

J Epidemiol Community Health 2006;60:751-756. doi: 10.1136/jech.2005.043794

See end of article for authors' affiliations

Correspondence to: Ms M Assunta, School of Public Health, Edward Ford Building, University of Sydney, NSW 2006, Australia; marya@health. usyd.edu.au

Accepted for publication 2 March 2006
Background: The Japanese government is an important shareholder in the Japanese tobacco industry. Negotiations to develop the WHO's historic Framework Convention on Tobacco Control (FCTC) were based on consensus, resulting in countries needing to agree to the lowest acceptable common denominator in clause development.

Objective: To illustrate Japan's role in negotiating key optional language in the FCTC text.

Methods: Summary reports, text proposals, conference papers, and speeches related to the six FCTC negotiation sessions were reviewed for repeated words, concepts and emerging themes. Key stakeholders were interviewed. Key words such as "sovereignty", "appropriate", "latitude", "individual", "flexibility", and "may" representing optional language were examined.

Results: The Japanese government's proposals for "appropriate" and optional measures are reflected in the final FCTC text that accommodates flexibility on interpretation and implementation on key tobacco controls. While Japan was not alone in proposing optional language, consensus accommodated their proposals.

Conclusion: Japan's success in arguing for extensive optional language seriously weakened the FCTC. Accordingly, international tobacco control can be expected to be less successful in reducing the burden of disease caused by tobacco use.
C n June 2004 Japan ratified the WHO Framework Convention on Tobacco Control (FCTC) being among the first 20 countries to do so. ${ }^{1}$ The ratification was described as an "extraordinary turn around" by the former head of the WHO's Tobacco Free Initiative ${ }^{2}$ and surprised many in global tobacco control who had long perceived Japan as a member of a triumvirate of nations with important tobacco interests that had shown strong signs of opposing international tobacco control. The Japanese government's substantial ownership* of the world's third largest transnational tobacco company, Japan Tobacco (JT), is seen by many as responsible for its weak tobacco control measures. Japan's decision to ratify the FCTC was said to have been done with "marked reluctance". ${ }^{3}$ During the negotiations, Japan along with the USA and Germany were viewed as working against the FCTC. ${ }^{4-6}$ Positions proposed by Japan were not consistent with achieving a stringent treaty capable of addressing several important platforms of tobacco control. What then motivated Japan to ratify the FCTC?

International treaty negotiation has been described as "an art, not a science, and the results are usually finely-balanced, living documents that often have to respond to different constituencies in a number of jurisdictions with different concerns and policy priorities. ${ }^{\prime 7}$ Experiences from other treaties, particularly in the environmental domain, suggest compromises are to be expected as treaties are forged by the constraints imposed by the need for consensus: "There is often a pronounced tendency toward lowest common denominator bargaining, where ambitious goals, mandated targets, and form timelines are either removed or diluted." ${ }^{8}$

*The Japanese government had a monopoly over the tobacco industry that dates back to 1904, and ended in 1985 after privatisation. However, the government is compelled by law (Tobacco Business Law) to own substantial portions of the shares 67\% until March 2002, and currently owns $50 \%{ }^{1439}$
This description exemplifies key aspects of negotiations for the FCTC, which was negotiated over three years (October 2000 to February 2003) and unanimously adopted by Member States of the WHA on May 23, 2003. While hailed as a historic health document designed to address a global epidemic, it has also been referred to as a pact with "weak binding force" designed to be supported by as many countries as possible. ${ }^{10}$

If the strength of a treaty lies in its language, the more optional language it has, the weaker the treaty will be. Wording permitting flexibility in interpretation and making compliance discretionary provides a weaker treaty than one containing obligatory language and requiring compliance.

Since 1970 the World Health Assembly (WHA) has adopted 18 Resolutions on different aspects of tobacco control. While these resolutions have often been referenced by nations when passing national tobacco control legislation, equally, their lack of any legally binding authority has made them inconsequential for many nations. ${ }^{11}$ Although the WHA adopted a resolution for the development of the FCTC in 1996, it was not till Dr Gro-Harlem Brundtland's election as director general of WHO in 1998 that work on the FCTC started in earnest. ${ }^{12}$ Brundtland set May 2003 as the deadline for the adoption of the FCTC that provided the impetus for negotiations to start. Just before the first negotiations in October 2000, WHO held a two day public hearing (12-13 October) the first time such a process had occurred in its history, to provide an opportunity for any interested party to present their views on the initial FCTC text. Representatives from 144 organisations and institutions gave oral testimonies

Abbreviations: FCTC, Framework Convention on Tobacco Control; JT, Japan Tobacco; JTI, Japan Tobacco International; WHA, World Health Assembly; INB, intergovernmental negotiating body; BAT, British American Tobacco; NGO, non-governmental organisation 
Table 1 Recent Japanese prime ministers in the context of milestones in FCTC

January 1996-July 1998

May 1998

October 1999-March 2000

April 2000-April 2001

12-13 October 2000

16-21 October 2000

April 2001-Present

30 April-5 May 2001

22-28 November 2001

18-23 March 2002

14-25 October 2002

17-28 February 2003

23 May 2003

30 June 2003

9 March 2004

8 June 2004

29 June 2004

27 February 2005
Ryutaro Hashimoto: viewed as pro-tobacco ${ }^{14}$

Dr Gro-Harlem Brundtland: appointed director general of WHO, FCTC made a priority project

Two Working Group meetings: WHO Member States drafted the initial FCTC text (chair's text) for the negotiations. ${ }^{15}$

Yoshiro Mori: appointed a pro-tobacco health minister who annihilated tobacco control efforts ${ }^{14}$

WHO Public Hearing on the proposed FCTC chair's text

First Session of the Intergovernmental Negotiating Body $(\mathrm{INB} 1)^{\dagger}$

Junichiro Koizumi: former Minister of Health who supported tobacco control efforts in his ministry

Second Session of the Intergovernmental Negotiating Body (INB2)

Third Session of the Intergovernmental Negotiating Body (INB3)

Fourth Session of the Intergovernmental Negotiating Body (INB4)

Fifth Session of the Intergovernmental Negotiating Body (INB5)

Sixth Session of the Intergovernmental Negotiating Body (INB6)

56th World Health Assembly unanimously adopted the FCTC

The FCTC was opened for signatures

Japanese government signed the FCTC

Japanese government ratified the FCTC

The FCTC closed for signatures with 168 signatories

FCTC entered into force and became legally binding for the first 40 countries that ratified the treaty

Source: http://www.who.int/tobacco/framework/en/;http://www.japan-zone.com/omnibus/

prime_minister.shtml

Table 2 Delegation size of selected countries to the INB negotiations in Geneva*

\begin{tabular}{lrrrrrr}
\hline Country & INB & INB2 & INB3 & INB4 & INB5 & INB6 \\
\hline Australia & 5 & 7 & 6 & 8 & 10 & 10 \\
Brazil & 10 & 11 & 14 & 12 & 9 & 9 \\
Canada & 13 & 17 & 14 & 16 & 16 & 17 \\
China & 13 & 18 & 14 & 20 & 18 & 18 \\
Germany & 6 & 7 & 7 & 8 & 11 & 8 \\
India & 5 & 5 & 5 & 6 & 8 & 8 \\
Japan & 7 & 7 & 10 & 13 & 18 & 20 \\
Russia & 10 & 14 & 23 & 26 & 21 & 18 \\
UK & 11 & 13 & 17 & 18 & 16 & 16 \\
USA & 9 & 12 & 15 & 14 & 16 & 17 \\
South Africa & 3 & 3 & 3 & 4 & 5 & 5 \\
\hline
\end{tabular}

Source: WHO FCTC web site: http://www.who.int/gb/fctc/. *Rationale for selection of countries: China, USA, Russia, Japan, and Brazil are the world's five largest tobacco manufacturers; USA, UK, Japan, and Germany are host to world's top tobacco transnational companies; Canada and Australia are developed countries with good tobacco control records; India and South Africa are developing countries to provide basis for comparison.

before a panel (online appendix l, http://www.jech.com/ supplemental) and WHO received 514 written submissions. ${ }^{13}$ Table 1 provides a summary of the main FCTC milestones.

WHO member states convened the INB and through six sessions negotiated the FCTC text. While each member state irrespective of size had equal negotiating status, Japan's participation presented particular interest because of its government's substantial ownership of and significant control over the operations of JT, a transnational corporation. Japan had an increasing presence at the negotiations, and by INB6 had the largest delegation of any nation (table 2).

The composition of the Japanese delegation also varied with the progress of the negotiations (on line appendix 2). At the first two INB sessions, Japanese's delegation consisted mainly of representatives from the Ministry of Health, Welfare and Labour and had no representation from the Ministry of Finance.ł However, by INB6 there were as many representatives from the Ministry of Finance as there were from the Ministry of Health reflecting the importance of input from the tobacco industry.

${ }^{\dagger}$ INB, the Intergovernmental Negotiating Body (INB) was opened to participation by all WHO member states, regional economic integration organisations and observers (as specified in resolution WHA52.18). The World Health Assembly charged the INB with the responsibility for negotiating the text of the WHO FCTC and possible related protocols (http://www. who.int/tobacco/framework/inb/en/index.html).
This paper considers Japan's proposals for the development and final wording of the FCTC. It examines how Japan was able to ratify the final text of the FCTC because significant sections of the text had by then been diluted to contain optional rather than obligatory language making the FCTC more acceptable to Japanese government concerns about the potential impact of such a treaty on its tobacco interests.

\section{METHODS}

Ninety six documents relevant to Japan from the WHO FCTC Documentation Centre were reviewed. These included summary reports-verbal comments made during formal negotiation sessions; conference papers (text proposals); speeches, and other relevant documentation (online appendix 3). These materials were reviewed for all sections pertaining to proposals made by the Japanese delegation related to the FCTC negotiations. The information was sorted under issues addressed in the FCTC Articles: general/definitions; objective/ guiding principles/obligations; tax measures; secondhand

FThe Ministry of Finance has direct and indirect influence over JT, including its overall policies. The participation of the ministry may be seen as representing tobacco industry interests. ${ }^{14}$ Similarly, Japan's Ministry of Agriculture, Forestry, and Fisheries has historically supported tobacco interests because of Japan's sizeable tobacco agricultural crop and the strong political constituency of tobacco farmers. 
Table 3 Summary of Original Chair's text and FCTC outcome

\begin{tabular}{|c|c|c|c|c|}
\hline Articles & Chair's text (INB1) & Japan Tobacco & Japanese government & FCTC Final Text 2003 \\
\hline $\begin{array}{l}\text { Packaging and } \\
\text { labelling: use of } \\
\text { "light and "mild" } \\
\text { Health warning }\end{array}$ & $\begin{array}{l}\text { Ban on terms such as } \\
\text { "light" and "mild" }\end{array}$ & $\begin{array}{l}\text { No ban on terms } \\
\text { "light" and "mild" }\end{array}$ & $\begin{array}{l}\text { Appropriate measures that terms } \\
\text { such as "light" and "mild" do } \\
\text { not convey impression tobacco } \\
\text { is less harmful. } \\
\text { May include a pictogram }\end{array}$ & $\begin{array}{l}\text { Labelling does not promote a false, } \\
\text { misleading, or erroneous } \\
\text { impression that may include terms } \\
\text { such as "light" or "mild". } \\
\text { May be in pictograms }\end{array}$ \\
\hline $\begin{array}{l}\text { Advertising, sponsorship, } \\
\text { and promotion }\end{array}$ & Strict restrictions & No total ban & Appropriate restrictions & A comprehensive ban or restrictions \\
\hline Vending machines & $\begin{array}{l}\text { Prohibit vending machines in } \\
\text { locations accessible to minors }\end{array}$ & No ban & $\begin{array}{l}\text { Appropriate measures to strictly } \\
\text { restrict the access of minors as } \\
\text { determined by domestic law }\end{array}$ & $\begin{array}{l}\text { Tobacco vending machines are not } \\
\text { accessible to minors. Parties may } \\
\text { commit to total ban }\end{array}$ \\
\hline Liability & $\begin{array}{l}\text { Take legislative action to deal } \\
\text { with liability and compensation }\end{array}$ & - & Delete text on liability & Consider legislative action \\
\hline Financial resources & $\begin{array}{l}\text { A voluntary mechanism for } \\
\text { financial resources }\end{array}$ & - & Delete text & $\begin{array}{l}\text { Promote, as appropriate, utilisation } \\
\text { of bilateral and multilateral funding }\end{array}$ \\
\hline
\end{tabular}

smoke; product regulation, ingredient disclosure, packaging and labelling; education; advertising/promotion; illicit trade reduction; sales to minors; manufacture and agriculturesubsidies; liability and compensation; research and surveillance; secretariat and financial resources (on line appendix 4). This provided a systematic index and facilitated analysis of the Japanese government's position.

Patterns of recurring concepts and words were identified from the information. ${ }^{16}$ Key words reflective of optional language such as appropriate, may,latitude, individual, sovereignty, and flexibility were selected to represent the concept of optional language that permitted flexibility in the interpretation of the treaty. These were used to examine how the Japanese government's proposals during the six negotiations (INBI-INB6) compared with $\mathrm{JT}^{\prime}$ 's opening statement at the Public Hearing. The final FCTC text was analysed to ascertain how closely it corresponded to the positions tabled by the Japanese government throughout the six negotiations. Media reports on Japan and the FCTC from online English language newspapers and tobacco industry magazines were reviewed. Nine interviews using semi-structured format were conducted, audiotaped, and transcribed involving key Japanese government officials from the Ministry of Foreign Affairs (one) and the Ministry of Health, Welfare and Labour (two plus a former official), Parliamentarian (one), and nongovernmental organisations (three), and former TFI head to verify and provide additional information on the material obtained from the FCTC negotiations.§

\section{RESULTS}

\section{Setting the tone}

Of 514 submissions to the WHO Public Hearing, public health submissions outnumbered those from the tobacco industry by $4: 1 .{ }^{17}$ Of the 144 oral testimonies presented (online appendix 1), $80 \%$ were supportive of the FCTC ensuring stringent tobacco controls, outlined the clear differences between public health goals and the economic objectives of tobacco companies, and wanted the tobacco industry to be excluded from the treaty negotiations. There were 15 submissions from Japanese institutions and organisations of which six $(40 \%)$ were pro-tobacco control and nine $(60 \%)$ pro-industry ${ }^{18}$ considerably contrasting with the ratio of overall submissions.

\footnotetext{
${ }^{\S}$ Attempts were made to interview officials who were part of the Japanese delegation at the negotiations, but many of them had since moved on and were unavailable for interview. The Ministry of Finance did not grant an interview, and although they agreed to provide written responses to questions, however the responses were never received. All information and interviews were obtained, reviewed, and analysed by
Assunta.
}

Significantly, JT's submission disagreed with the fundamental objective of the Convention to reduce tobacco consumption. ${ }^{19}$ It used the words "sovereign" or "sovereignty" 11 times to emphasise the importance of recognising the autonomy of governments (online appendix 5), arguing governments should be left free to decide the nature of tobacco control regulations and not be forced to implement one set of standards such as those embodied in the FCTC. In other words the FCTC should be broad and flexible, not prescriptive.

JT used the word "appropriate" eight times in its fiveminute presentation (online appendix 5) calling for: "appropriate regulation", "regulatory framework that is appropriate to society and culture", "appropriate separation of smokers and non-smokers", "appropriate protection of confidentiality", and that the Convention's objectives have already been addressed appropriately by Member States. Examples of JT's appropriate measures included no total ban on tobacco advertising and no ban on brand descriptors such as "light" and "mild" on cigarette packs (table 3). These propositions coincided with key issues specified by the Japanese government during their negotiations.

Like JT, BAT also used the word appropriate associatively with regulation, standards, and public policy. In its submission to the public hearing, BAT used the word appropriate 14 times to describe the kind of regulation it supported (online appendix 6). WHO's director general, commenting on the public hearing submissions, referred to the tobacco industry's call for appropriate measures that she described as ineffective and "measures that are known to have a very limited impact on youth and adult consumption of tobacco." ${ }^{\prime 20}$

The Japanese delegation's proposals during the six INB sessions were closely aligned with JT's propositions (table 3 and online appendix 7). JT's emphasis on the importance of respecting "individual governments", of not "infringing on sovereignty of governments", and leaving it up to the "sovereign governments to determine legislative and regulative framework" was supported by Japan in its proposal to "leave decisions in specific matters to individual governments". Japan favoured a general treaty that could be ratified by the largest number of countries. The idea of giving flexibility and latitude, another implicit proposal of JT, was proposed and maintained by Japan throughout the negotiations.

At the first INB, Japan proposed to "allow Member States a certain degree of latitude in determining the specific measures", ${ }^{21}$ and that such measures need not just be

"In 2000 other countries calling for a broad treaty included the USA, Germany, Russia, India, China, Argentina, Zimbabwe, Malawi, and Turkey, all nations with significant tobacco industries. (http://bat. library.ucsf.edu/tid/ylk93a99) 
legislative but also could include "administrative measures" permitting further flexibility in implementation necessary for fulfilling an obligation (online appendix 8). In the final negotiation session Japan maintained a "framework convention on tobacco control should be both effective and flexible enough to take into account the differing circumstances of individual countries."22

\section{Optional language in the treaty}

The final FCTC text reflects the optional language proposed by Japan throughout the negotiations (online appendices 9 and 10) especially in the clauses that the Japanese delegation identified as four key issues namely packaging and labelling; advertising and promotions; liability and financial resources (table 3). ${ }^{22}$

\section{"Appropriate"}

Like JT, the Japanese government used "appropriate" at least 34 times in its proposals over the six INB sessions (online appendix 4). They supported the "development of an appropriate international framework convention on tobacco

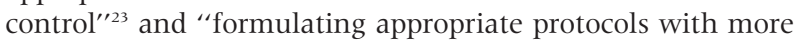
detailed contents than the convention." ${ }^{24}$ The Ministry of Foreign Affairs believed flexibility and the use of the term appropriate in the FCTC was a positive thing for all countries:

\section{"It's what we really insisted on. That's because unless we put it that way it will be very difficult not only for us but for many other countries to actually comply with the conven- tion. If not, they will never be able to ratify the convention." (interview granted to Mary Assunta with official of Ministry of Foreign Affairs).}

The Chair's text referred to a "ban on tobacco advertising direct and indirect, promotion and sponsorship targeted at persons under 18 years" and imposed "strict restrictions" for those targeted to adults aged over 18. Japan negotiated to replace "strict restrictions" with "appropriately restrict" and "any form of sponsorship" with "tobacco brand sponsorship" 26 meaning that tobacco companies would be allowed to advertise using their company name and that "appropriately restrict" would be left open to interpretation by Member States. The final FCTC text ensures flexibility and gives governments the choice to either ban or "restrict". ${ }^{27}$ The word "appropriate" appears 62 times in 19 Articles including the Preamble in the final FCTC text (online appendix 9).

\begin{abstract}
"May"
The Japanese delegation proposed that the word "may" be added to several clauses. For example, it proposed a "general health warning which may rotate and include a picture or pictogram as prescribed by national authorities." ${ }^{28}$ The Chair's text had proposed each package should carry a health warning including a pictogram and terms such as "low tar" and "light" and "mild" not be used on any tobacco package. Japan's position was not a prohibition of descriptors but rather appropriate measures to ensure that these terms did not "convey the impression that a tobacco product is less harmful to health of others." ${ }^{28}$ The final text reflects health warnings may include pictograms and may (our emphases) include terms such as "light" and "mild" (table 3). The word "may" appears 27 times in 16 Articles, including the four key issues (online appendix 7).
\end{abstract}

\section{"Or other measures"}

Another substantial weakening of the text was adding the phrase "or other measures" to "legislative, executive or administrative" measures. The Japanese government proposed adding "other appropriate measures" to text that addressed protecting the public from exposure to tobacco smoke. They explained: "In Japan passive smoking had been significantly reduced without recourse to legislation, through a combination of measures, including administrative ones." 29 The implications of this are important because vague, indefinable terms provide further flexibility for non-compliance and/or encourage avoidance of additional legislation or government control.

\section{"According to national law"}

Another vehicle for flexibility was the use of the phrase "according to national law", ${ }^{28}$ which Japan proposed several times. For example, on labelling: "adoption and implementation of appropriate measures, in accordance with national law, to ensure that..." This flexibility means wording on cigarette packs can be adjusted without enacting new laws. At INB3, Japan proposed another flexible phrase, "within the means at its disposal and its capabilities" ${ }^{\prime 30}$ to infuse flexibility into the text for price and tax measures, and cigarette sales to minors, (online appendix 4). At INB4, the African region deemed that the phrase "according to its capabilities" could weaken the convention, possibly providing a loophole allowing some Member States to avoid complying with its terms. ${ }^{31}$ Similarly the South East Asian region opposed the use of this phrase saying it was simply redundant. ${ }^{32}$

\section{Deletion of text}

Japan called for deletion of text at least 35 times during the course of the six negotiations if the text was too prescriptive or stringent. For example, on ingredient listing, Japan proposed that the word "all" should be deleted from "all ingredients" 133 and that "including counter advertising" deleted as an education and public awareness strategy. At INB6, Japan called for a deletion of the text on liability. The final FCTC text on liability is a loosely worded option to parties to "consider taking legislative action where necessary to deal with criminal and civil liability including compensation." ${ }^{27}$

The Chair's text called for financial resources to be provided both nationally and internationally. Internationally, the text called for a voluntary mechanism for the provision of financial resources on a grant or concessional basis. At INB3 the Japanese government said it could not support a compulsory mechanism in the form of a multilateral global fund. Neither could it support the proposal to target the tobacco industry as a means of raising financial resources. At the final negotiation session, Japan called for the text to be deleted. The final outcome was a weakly worded clause calling Parties to "promote, as appropriate, the utilisation of bilateral, regional sub-regional, and other multilateral channels to provide funding for the development and strengthening of comprehensive tobacco control programmes of developing country Parties and parties with economies in transition."

\section{DISCUSSION}

As the FCTC negotiations were resolved by consensus and not by vote, countries agreed to the lowest common denominator. The end result is a far weaker treaty than the original Chair's text. After four rounds of negotiations, at the fifth INB in October 2002, the director general acknowledged that the text had fallen short of her expectations but was a "good starting point". ${ }^{35}$ By the final negotiation the director general appealed to countries to support a draft that could command broad support. ${ }^{36}$

Although the text is the sum result of negotiations among the WHA Member States, Japan's significant role in 


\section{What this paper adds}

This is the first paper to analyse a country's influence in the WHO Framework Convention on Tobacco Control (FCTC) negotiations and the outcome as reflected in the final text of the treaty. While there have been news reports and anecdotal reference to Japan's obstructive role during the FCTC negotiations, this is the first paper to analyse their specific language proposals for the text made during the negotiations. This is also the first paper that addresses the element of optional language that provides for flexibility (read weakness) in the FCTC.

contributing to the dilution of the final wording of the FCTC must be recognised. The final FCTC text reflects that Japan's positions were accommodated (online appendix 10). As the principle of consensus drove the negotiations, any country proposing a weaker position was accommodated.

Japan's negotiating stance was anticipated by the former director of TFI:

"[O]ne has to look at that in the context of how Japan generally wants to put forward legislation. They are anti any legislation that is clearly going to require businesses to change their practices, without giving them this extraordinary leeway of self-regulation. And that is not just tobacco specific. ... If you follow their approach to food policy, the pharmaceutical regulation, the marketing in general, the same kind of language applies." (interview granted to Mary Assunta with Derek Yach, former director of Tobacco Free Initiative WHO).

This is consistent with Japan's stance in other treaty negotiations proposing text to "tone down", 1438 avoid mandatory obligation, and rephrasing explicit terms with indefinable and vague wording. ${ }^{39}$ While comprehensive legislation is regarded as being at "the heart of effective tobacco control" 40 this view is not shared by Japan. According to the Japanese government, if other measures rather than legislation could be as effective, that would serve the same purpose:

"So, appropriate measure is very crucial for us. ... If we really need to change the law, that will take many years. With guidelines it will work but with less time." (interview granted to Mary Assunta with official of Ministry of Foreign Affairs).

Japan's compliance record with other treaties has raised scepticism about real change forthcoming and perhaps the future of FCTC implementation in Japan may be "precarious" (Levin M. Personal communication, 8 Dec 2005). A senior Japanese government officer writing unofficially after the FCTC was adopted noted "no implementing of legislation or budgetary action is necessary" for Japan to comply with FCTC obligations. ${ }^{41}$ The commentary suggested Japan was already taking necessary steps to comply with several clauses of the FCTC such as revising pack health warnings to a minimum of $30 \%$ of the pack face that was phased in by 30 June $2005^{42}$ and restricting tobacco advertising. ${ }^{41}$ While countries have the option of applying a more stringent interpretation of the health warning by introducing graphic warnings on packs, Japan opted to introduce only textual warnings. ${ }^{* *}$

\section{Policy implications}

The flexibility in the FCTC language offers an ostensible excuse for the Japanese and/or other Parties to the Convention to avoid development of robust comprehensive tobacco control policies. To fulfil the main objective of the FCTC to reduce tobacco consumption and reduce its burden on society, the strongest interpretation and implementation of the FCTC must be applied.

During the FCTC negotiations international and local media applied pressure on Japan to re-examine its stance on tobacco control. ${ }^{44-46}$ Typically the government was criticised for its failure to recognise the importance of the $\mathrm{FCTC}^{47}$ calling on the government to strengthen its smoking controls before the adoption of the treaty in 2003. A Ministry of Foreign Affairs official confirmed that the media's interest and public support for Japan to ratify the FCTC was, "much bigger than I really expected."25

Outside Japan, international NGOs participating in the FCTC negotiation played a part in keeping pressure on the Japanese government by meting out public shame such as the awarding of "Dirty Ashtray Awards" (of which Japan received the most) over its weak negotiating positions. ${ }^{48}$ In March 2002 at INB4, Japan was labelled by an NGO as one of the "axis of evil". This had an impact on Japan's negotiating stance because the officials were "shocked to be blamed and to be framed as such." (interview granted to Mary Assunta with former official of Ministry of Health). According to the Anti Smoking Parliamentarian League the "axis of evil" label became an effective lobbying "key word" providing "political leverage". (interview granted to Mary Assunta with Member of House of Counselors from Anti Smoking Parliamentaman League).

Anticipating pressure to ratify the treaty from domestic and foreign sourcest† and also facing countervailing pressures to protect domestic tobacco industry interests, the Japanese government seemed to have searched for a strategy that would appease both interests. Following earlier methods applied in other treaty negotiations, a weakened treaty text was a practical middle way. ${ }^{14} 38$ The final FCTC text is compatible with Japan's position and has sufficient optional language particularly in crucial issues to provide sufficient room to manoeuvre.

Japan's behaviour throughout the FCTC negotiations was presumably motivated by a concern to minimise any impact on JT's abilities to maximise domestic and export tobacco sales. While negotiations were proceeding, JT and JTI aggressively fought European efforts ${ }^{51}{ }^{52}$ and after ratification, Asian moves s $^{53}$ to abolish misleading descriptors like "light" and "mild". Japan's success in arguing for optional language weakened the

"* Based on Article 36 (Tobacco Business Law Enforcement Regulations) under Article 39 health warnings on packs were revised. The revised regulations provide four types of warnings on direct effects of smoking and four others. Each tobacco package must contain at least two warnings - one direct effect and another from the others. Example of warning from direct effect: "Smoking is one cause of lung cancer. According to epidemiological studies, the risk of smokers dying from lung cancer is estimated to be two to four times greater than that for nonsmokers." This warning is followed by the address of the Health Ministry's web site.

${ }^{\dagger \dagger}$ Interview with former head of TFI: "I think there was a growing pressure. You must remember the world situation was one where countries were being grouped into those who believed in multilateralism and the rule of the UN and international law Vs the US and the polarization was rising. But Japan wanted to be aligned with all of those who were going to be part of the multilateral system. They themselves have played consistent and strong support to being part of that multilateral system." (28 April 2005) 
FCTC. Accordingly, international tobacco control can be expected to be less successful in reducing the burden of disease caused by tobacco use if parties do not go beyond the minimum standards outlined in the FCTC.

\section{ACKNOWLEDGEMENTS}

Stacy Carter PhD for editorial comments.

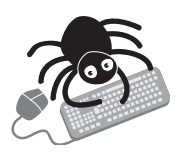

The appendices are available on line (http:// www.jech.com/supplemental).

\section{Authors' affiliations}

M Assunta, S Chapman, School of Public Health, University of Sydney, Australia

Funding: none.

Competing interests: Mary Assunta is the Chair of the Framework Convention Alliance (FCA). Simon Chapman is the editor of Tobacco Control, a board member of Action on Smoking and Health (Australia) and the Cancer Council NSW

\section{REFERENCES}

1 The World Medical Association. The WHO Framework Convention on Tobacco Control on track to become law by the end of the year. World Medical Journal 2004;50:77-8.

2 Yach D. Injecting greater urgency into global tobacco control. Tob Control 2005; 14:73-144

3 Boyd A. Asians kick big tobacco in the butt. Financial Express, 2005;15 Mar. http://www. financialexpress-bd.com/index3.asp?cnd = 3/15/ 2005\&section_id = 17\&newsid = \&spcl=yes (accessed 17 Mar 2005)

4 Nullis C. World: WHO chief renews attack on tobacco 2002. http://0global.factiva.com.opac.library.usyd.edu.au/en/eSrch/ss_hl.asp (Accessed 17 May 2005)

5 Campaign for Tobacco Free Kids. Tobacco treaty negotiations make progress despite continued U.S. efforts to weaken key provisions 2001. http:// www.tobaccofreekids.org (accessed 17 May 2005).

6 Fisher Brinson B. Who's in control? Tobacco Reporter, 2003;Jul. http:// www.tobaccoreporter.com

7 Wilkie C. The origins of NAFTA investment provisions: economic and policy considerations. Carlton University, 2002. http://www.carleton.ca/ laccessed 13 May 2005).

8 World Resource Institute. International environmental governance: the changing face of environmental agreements. Washington, DC: World Resource Institute, 2003;328. (World Resources 2002-2004: Decisions for the Earth: Balance, voice and power. http://pubs.wri.org/ pubs_content_text.cfm?ContentID = 1802 .

9 World Health Organisation. World Health Assembly adopts historic Tobacco Control Pact. Geneva: WHO, 2003. http://www.who.int/mediacentre/ news/releases/2003/prwhal/en/ (accessed 21 Mar 2005).

10 Hanai K. Weak tobacco pact reflects Japan's lukewarm attitude. Japan Times 2003; 25 Mar. http://www.japantimes.co.jp/cgi-bin/ getarticle.pl5?eo20030325kh. htm (accessed 24 July 2004).

11 World Health Organisation. The Framework Convention on Tobacco Control: a primer. Geneva: WHO, 1999. http://whqlibdoc.who.int/hq/ 2003/WHO_NCD_TFI_99.8_Rev.7.pdf) (accessed 21 Mar 2005).

12 Roemer R, Taylor A, Lariviere J. Origins of the WHO Framework Convention on Tobacco Control. Am J Public Health 2005;95:936.

13 World Health Organisation. Public hearings on the Framework Convention on Tobacco Control: Submissions. Geneva: World Health Organisation, 2000. http://www3.who.int/whosis/fctc/fctc.cfm (accessed 5 Mar 2005).

14 Levin M. Tobacco industrial policy and tobacco control policy in Japan. Tokyo, 2004;298-318. (Tobacco Free Japan: recommendations for tobacco control policy.

15 World Health Organisation. Proposed draft elements for a WHO framework convention on tobacco control: provisional texts with comments of the working group (A/FCTC/INB 1/2). Geneva: World Health Organisation, 2000. http://www.who.int/gb/fctc/ (accessed 3 Mar 2005).

16 Ryan GW, Bernard HR. Techniques to identify themes. Field Methods 2003;15:85-109.

17 World Health Organisation. Secretariat update: public hearings on the Framework Convention on Tobacco Control. Geneva: World Health Organisation, 2000. http://www.who.int/gb/fctc/PDF/inbl/el inbid1.pdf (accessed 11 Jun 2005)

18 Tobacco Free Initiative WHO. Public hearings. Geneva: World Health Organisation, 2000. http://www.who.int/tobacco/framework/ negotiations/en/ (accessed 3 Mar 2005).
19 Japan Tobacco. Comments by Japan Tobacco on the proposed Framework Convention on Tobacco Control. Geneva: World Health Organisation, 2000. http://www.who.int/tobacco/framework/negotiations/en//accessed 3 Mar 2005)

20 World Health Organisation. WHO director-general's response to the tobacco hearings. Geneva: World Health Organisation, 2000. http://www.who.int/ inf-pr-2000/en/state2000-06.html (accessed 12 May 2005).

21 World Health Organisation. Provisional Summary Record of the Meeting 18 October 2000. (A/FCTC/INB1/PL/SR/6). Geneva: World Health Organisation, 2000.

22 World Health Organisation. Provisional Summary Record of the First Plenary Meeting (A/FCTC/INB6/PL/SR/1 Corr 1). Geneva: World Health Organisation, 2003 (accessed 3 Mar 2005).

23 World Health Organisation. Provisional Summary Record of the Meeting (A) FCTC/INB5/PL/SR/1). Geneva: World Health Organisation, 2000;15 Oct.

24 World Health Organisation. Provisional Summary Record of the Meeting (A) FCTC/INB1/PL/SR/3). Geneva: World Health Organisation, 2000;17 Oct.

25 Reference withdrawn.

26 World Health Organisation. Drafting and negotiation of the WHO framework convention on tobacco control: textual proposals and definitions submitted for the new Chair's text by 15 May 2002. (A/FCTC/INB5/3). Geneva: World Health Organisation, 2002;6 Aug.

27 World Health Organisation. WHO Framework Convention on Tobacco Control. Geneva: World Health Organisation, 2003;http://www.who.int/ tobacco/framework/download/en/index.html (accessed 3 Mar 2005)

28 World Health Organisation. Textual proposal and definitions submitted for the new Chair's Text by 15 May 2002. (A/FCTC/INB5/3). Geneva: World Health Organisation, 2002:5 Aug.

29 Intergovernmental Negotiating Body (INB)2. Working Group 1: Summary report. Geneva: World Health Organisation, 2001;30 Apr.

30 World Health Organisation. Provisional Summary Record of the First Meeting 22 November 2001. (A/FCTC/INB3/WG1/SR/1). Geneva World Health Organisation, 20021 Feb.

31 AFRO Region. [AFRO Region's proposal on non-price measures at IN4 INB4/WG1/SR/1]. Geneva: World Health Organisation, 2002;8 Mar. http://www.who.int/gb/fctc

32 South East Asian Region. [South East Asian Region's proposal on non-price measures at IN4 - INB4/WG1/SR/1]. Geneva: World Health Organisation, 2002; 18 Mar. http://www.who.int/gb/fctc

33 World Health Organisation. Provisional Summary Record of the Second Meeting 24 November 2001. (A/FCTC/INB3/WG1/SR/2). Geneva: World Health Organisation, 2002;7 Feb.

34 World Health Organisation. Provisional Summary Record of the Third Meeting 25 November 2001. (A/FCTC/INB3/WG1/SR/3). Geneva: World Health Organisation, 2002;7 Feb.

35 Kapp C. Brundtland pleas for tough tobacco treaty meet reality. Lancet 2002;360:1231.

36 Kapp C. Tobacco-control treaty language approved despite objections. Lancet 2003;361:839-40.

37 Reference withdrawn.

38 Iwasawa Y. International law, human rights, and Japanese law: the impact of international law on Japanese law. New York: Clarendon Press, 1998.

39 Levin MA. Smoke around the rising sun: an American look at tobacco regulation in Japan. Standford Law and Policy Review 1997;8:99-123.

40 Blanke DD, da Costa e Silva VL, eds. Tobacco control legislation: an introductory guide. 2nd ed. Geneva: World Health Organisation, 2004:15-20.

41 Nakamura K, Foreign Ministry Treaty Bureau. Enacted Laws of the 159th session of the Parliament, "The WHO's Framework Convention on Tobacco Control". Jurist: Special Issue 2004;1274:85-95.

42 Japan Tobacco. Annual report 2005. Tokyo: Japan Tobacco, 2005;120. http://www.jit.co.jp/JTI_E/IR/05/annual2005/annual2005_E_all.pdf

43 Reference withdrawn

44 Mitchell H. Japan's tobacco industry tradition in transition. Bangkok Lockwood, 2005. http://www.tobaccoasia.com/news. asp?id = 845 (accessed 7 Mar 2005)

45 Hanai K. Blowing smoke on tobacco. Japan Times, 2004;24 May. http:// www.japantimes.co.jp/cgi-bin/makeprfy.pl5?eo20040524kh.htm laccessed 25 May 2004)

46 Matsubara $\mathbf{H}$. Japan slowly pulls head out of sand on smoking ills. Japan Times, 2003;22 Oct. http://www.japantimes.co.jp/cgi-bin/ makeprfy.pl5?nn20031022a4.htm (accessed 27 Oct 2003)

47 Japan Times. Time to get tough on tobacco. 1 Jun 1999. Philip Morris. Bates No. 2064812282/2283. http://legacy.library.ucsf.edu/tid/tve24c00 (accessed 31 May 2005).

48 Framework Convention Alliance. Of orchids, ashtrays and the human spirit. 28 Feb 2003. http://fctc.org/bulletin/Issue_45.pdf (accessed 1 Jun 2005).

49 Reference withdrawn.

50 Reference withdrawn.

51 Japan Tobacco. Press Release: JT and JTI launch legal challenge against EU tobacco directive. Tokyo: Japan Tobacco, 2001;20 Sep. http://www.jti.com/ english/press_room/press_releases/pr_article_20_09_2001.aspx

52 Japan Tobacco. Press Release: JT and JTI disagree with European Court of Justice decision to uphold Tobacco Products Directive. Tokyo: Japan Tobacco, 2002;10 Dec. http://www.jti.co.jp/JTI_E/Release/02/r_justice.html

53 Moy P. Mild Seven ban would ruin city's free-trade image, lawyer warns. South China Morning Post 2005; 7 Oct. 